\title{
ON THE WAY TO DEVELOP OPEN APPROACH TO MATHEMATICS IN FUTURE PRIMARY SCHOOL TEACHERS
}

\author{
Libuše Samková ${ }^{\bowtie}$, Marie Tichá ${ }^{2}$ \\ ${ }^{1 \bowtie}$ Department of Mathematics, Faculty of Education, University of South Bohemia, Jeronýmova 10, České Budějovice, 371 15, Czech Republic, \\ +420 387773 091, 1samkova@pf.jcu.cz \\ ${ }^{2}$ Department of Didactics of Mathematics, Institute of Mathematics of the Czech Academy of Sciences, Czech Republic
}

\author{
Highlights \\ - $\quad$ Active participation in inquiry-based mathematics course can develop open approach to mathematics \\ - Concept Cartoons - a tool with supportive, educational, and diagnostic role in teachers' education
}

In our contribution we focus on the possibility to develop open approach to mathematics in future primary school teachers during a university course on mathematics conducted in inquiry-based manner. In the first part of the research we analyse data obtained in the beginning and in the end of the mathematics course with respect to two main aspects related to open approach to mathematics: searching for all solutions of a task, and acceptance of different forms of notation of a given solution. Data analysis revealed in the participants three different shifts towards open approach to mathematics, and showed that after the active participation in the course each of the participants improved at least in one of the monitored aspects, and that none of the participants got worse in any of the aspects. In the second part of the research we analyse problems posed by participants several months after the end of the course, again with respect to the two aspects related to open approach to mathematics. As a special diagnostic instrument in our research we use an educational tool called Concept Cartoons.

\author{
Article type \\ Full research paper \\ Article history \\ Received: April 30, 2016 \\ Received in revised form: June 17, 2016 \\ Accepted: June 17, 2016 \\ Available on-line: June 30, 2016
}

\section{Keywords}

Argumentation, Concept Cartoons, future primary school teachers, inquiry-based mathematics education, open approach, problem solving and problem posing

Samková L., Tichá M. (2016) "On The Way to Develop Open Approach to Mathematics in Future Primary School Teachers", Journal on Efficiency and Responsibility in Education and Science, Vol. 9, No. 2, pp. 37-44, online ISSN 1803-1617, printed ISSN 2336-2375, doi: 10.7160/eriesj.2016.090202.

\section{Introduction}

The study reported here is a part of a three-year qualitative educational research conducted under Czech Science Foundation project. The goal of the project is to implement inquiry-based education into university courses on mathematics and didactics of mathematics for future primary school teachers, and observe how active participation in these courses can influence professional competences of project participants, i.e. their knowledge, beliefs, and practice.

In this particular study we focus on developing project participants' open approach to mathematics during the course on mathematics. Our research questions are "What shifts towards open approach to mathematics can be observed in future primary school teachers after their active participation in an inquiry-based university mathematics course?" and "Do the shifts towards open approach observed when participants solve problems appear also when they pose problems?" For the purpose of the research on the first research question we shall assign open problems to future primary school teachers in the beginning and in the end of the inquiry-based university course on mathematics, and in consideration of open approach we shall observe whether there occur any changes in the way how they solve and justify the problems. For the purpose of the research on the second research question we shall analyse problems posed by future primary school teachers in the time after the course, and observe whether the posed problems allow to engage open approach to mathematics when used in the classroom. Both the assigned and posed problems will be in the form of a special educational tool called Concept Cartoons.

From the perspective of ERIE conferences and ERIES journal, the topic of our contribution is a broad-based one. Since it deals with developing problem-solving skills, it is in relation not only to educational issues such as students' ability to solve mathematical problems (Novotná et al, 2014; Novotná, Eisenmann and Přibyl, 2015) or future engineers' creativity (Zhou, 2012), but also to managerial issues such as decision making or managerial competencies (Hricová, 2015). Moreover, the study deals with problem posing which is in relation to teachers' ability to pose mathematical problems (Patáková, 2013).

The paper has been developed as an extension of the contribution (Samková and Tichá, 2016c).

\section{Inquiry-based education}

Inquiry as a pedagogical concept can be traced long way back to the work of Dewey (1938: 104-105) who introduced it as 'the controlled or directed transformation of an indeterminate situation into one that is so determinate in its constituent distinctions and relations as to convert the elements of the original situation into a unified one', and characterized the indeterminate situations as 'disturbed, troubled, ambiguous, confused, full of conflicting tendencies, obscure, etc.' .

On the other hand, nowadays inquiry-based pedagogy is used to be defined as a way of teaching in which students are invited to work in ways similar to how scientists work (Artigue and Blomhøj, 2013), i.e., to observe, pose questions, reason, think, search for relevant information, collaborate, collect data and interpret them, to solve and discuss problems that come out from real life or can be applied in everyday life contexts (Dorier and Maßß, 2014). From this point of view we can understand 
inquiry-based mathematics education as a propaedeutic of both pure and applied mathematics.

Although the term inquiry is more common in the field of science education, and its appearance in the field of mathematics education is rather a matter of recent, the idea of inquiry is in accordance with educational frameworks that appeared in mathematics long before the term: problem solving, theory of didactical situations, realistic mathematics education, mathematical modelling, anthropological theory of didactics, dialogical and critical approaches (for details on these frameworks and their coherence with inquiry see Artigue and Blomhøj, 2013), problem posing (Tichá, 2009; Singer, Ellerton and Cai, 2015), substantial learning environments (Wittmann, 2001), and many others. Also by looking into the Czech past we can find research content close to the concept of inquiry: the concept of guided rediscovery (Vyšín, 1976), built on characteristics of genetic style of teaching of Brunner (1966), Wittmann (1974) and Freudenthal (1973), the concept of strengthening contact of mathematics education with everyday reality and with other school subjects (Koman and Tichá, 1988), or grasping of situations (Koman and Tichá, 1998).

In mathematics, the starting point for inquiry activities of pupils consists in creating an appropriate learning environment, usually in the form of a task or a problem that pupils have to solve. In accordance with Dewey, in order to stimulate enough inquiry activities of pupils, the task should contain something unknown for the solver what is perceived by the solver as thoughprovoking or interesting. But inquiry is possible only when this unknown part can be approached through something known, for only known facts and their relations might lead to conjectures and judgments that allow the solver to seek the solution.

For more details on inquiry-based mathematics education see also a survey study written by Samková et al (2015).

\section{Open approach to mathematics}

Open approach to mathematics is a method that is in accordance with the above mentioned educational frameworks. Within this approach the teachers assign the students problems that are called open - problems whose starting or goal situation is not exactly given. Open problems have multiple levels of grasping (i.e. the starting situation is open), multiple correct ways of solving (i.e. the process is open), multiple correct answers (i.e. end products are open) or multiple ways to transform the problem into a new one (i.e. ways to develop are open). Generally, solving an open problem may consist of various ways of formulating the problem mathematically, of investigating various approaches to the formulated problem, and of posing various advanced problems (Nohda, 1995, 2000; Pehkonen 1995).

When solving open problems, students' responses can be evaluated according to fluency (how many solutions the student produced?), flexibility (how many mathematical ideas the student discovered?), originality (to what degree is the student's idea original?), and elegance (to what degree is the student's explanation simple and clear?) (Nohda, 2000).

Open problems may arise from school mathematics as well as from real-life settings. In the latter case, a very important part of solving the problem consists of grasping the situation, i.e. by putting oneself into the position of the person involved in the situation, by reviving former experiences and accumulated knowledge from everyday life which are close to the given situation, and by judging the results from the point of view of the person involved (Koman and Tichá, 1998).

A special class of open problems called polyvalent math tasks (polyvalenten Aufgaben) was introduced by Hellmig (2010). These tasks have multiple solutions, the solutions correspond to different levels of mathematical knowledge, and every student is probably able to find a solution.

\section{Materials and Methods}

\section{Participants}

Participants of the referred study were 29 future primary school teachers, completely all students of the second year of five-year master degree program at the Faculty of Education. They are not math specialists; after graduation they are expected to teach all primary school subjects (languages, mathematics, science, arts, physical education, etc.).

These students actively participated in one-year course on mathematics held in inquiry-based manner. The course focused on introduction to logic, set theory, and number systems; it had a range of three hours per week.

During the seminars of the course the students participated in so-called guided inquiry, i.e. inquiry when the teacher provides the students with problems or questions, and the students have to find the appropriate problem-solving strategies and methods (for characterization of various types of inquiry see Bruder and Prescott, 2013).

\section{Diagnostic instrument}

As a diagnostic instrument in our study we innovatively use a primary-school educational tool called Concept Cartoons (Keogh and Naylor, 1993). Each Concept Cartoon is a picture showing a situation well known to pupils from school or from everyday reality, and a group of children in a bubble-dialogue. The texts in the bubbles present alternative viewpoints on the situation or alternative solutions of a problem arising from the situation, regardless of their correctness; the correctness may also be unclear or conditional. For a sample see Fig. 1.

Concept Cartoons were developed more than 20 years ago. Its original goal was to support teaching and learning in science classroom at primary school level by generating discussion, stimulating investigation, and promoting learners' involvement and motivation. In later years the tool also expanded to other school subject, including mathematics. When working with Concept Cartoons, pupils have to choose all children that are right, and justify their choice.

Authors of Concept Cartoons performed several researches on the use of Concept Cartoons in primary school science classroom, one of them (Naylor, Keogh and Downing, 2007) showed that the lack of agreement amongst the pictured children encourages pupils to join the discourse with their own opinions, and that such discourse can take a form of sustainable and purposeful argumentation.

In our project we take advantage of this supportive argumentation feature, and innovatively use Concept Cartoons for diagnosing various types of future primary school teachers' mathematics knowledge. We work on establishing a typology of 
Concept Cartoons that are applicable as a diagnostic tool, and on creating our own database of Concept Cartoons suitable for this purposes (Samková and Naylor, 2015; Samková, Tichá and Hošpesová, 2015). Our recent research on this issue shows that Concept Cartoons can be helpful in identifying various aspects of the process of grasping of a situation (Samková and Tichá, 2015), and that suitably chosen Concept Cartoons allow us to distinguish between subject matter knowledge and pedagogical content knowledge as well as between procedural knowledge and conceptual knowledge (for details see Samková and Hošpesová, 2015).

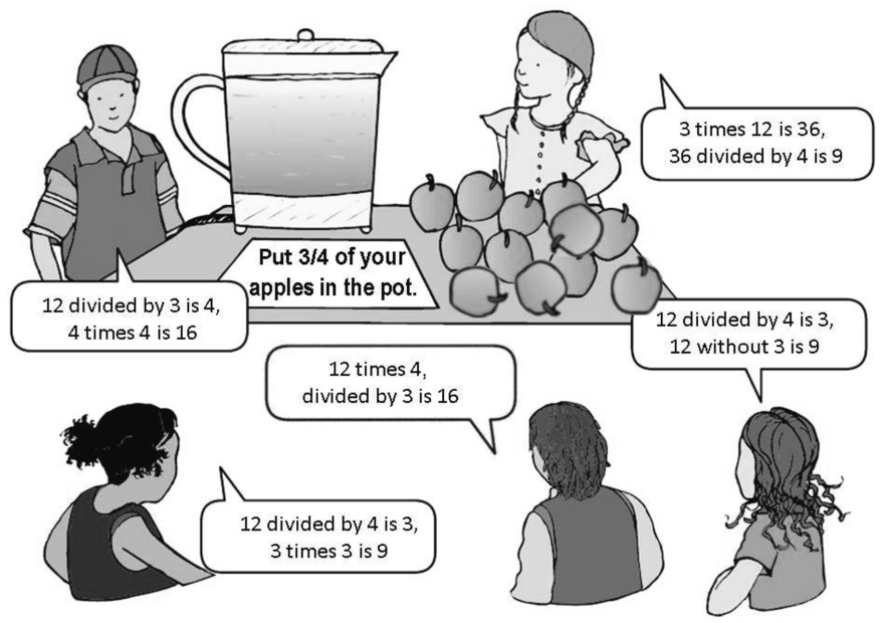

Figure 1: Concept Cartoon with three correct bubbles based on three different models of fractions, and with two incorrect bubbles, one of them being the most frequent pupils' misconception (source of the template of children with empty bubbles: Dabell, Keogh and Naylor, 2008: 3.10).

During the inquiry-based university mathematics course we continuously assigned students various Concept Cartoons in order to detect changes in various aspects of their mathematical knowledge. Altogether we proposed them 21 Concept Cartoons, 6 of them related to open approach to mathematics (e.g. the one in Fig. 1 which is based on three different correct ways of solving the pictured task; this task is also polyvalent in the sense of Hellmig, 2010).

\section{First part of the research: open approach in problem solving}

The first part of the research relates mainly to problem solving. It aspires to look for answers to the research question "What shifts towards open approach to mathematics can be observed in future primary school teachers after their active participation in an inquiry-based university mathematics course?"

In this part of the research data collection took place in two stages: in the beginning and in the end of the school year. In both cases we assigned the participants a worksheet with a Concept Cartoon, and asked them to choose in the picture all the children that are right, and to justify their choice. For the purpose of data collection the participants worked on the worksheets individually, during a lesson.

In the beginning of the school year we assigned the students the Concept Cartoon shown in Fig. 2. The task discussed in the picture has two solutions: the first one is directly described in a bubble B (here the missing digits are ordered like the child reads them from a sheet with a completed task) and also in a bubble A (here the missing digits are ordered from the smallest), the second one is not described in any bubble, its possible existence is just indirectly mentioned in a bubble $\mathrm{E}$.

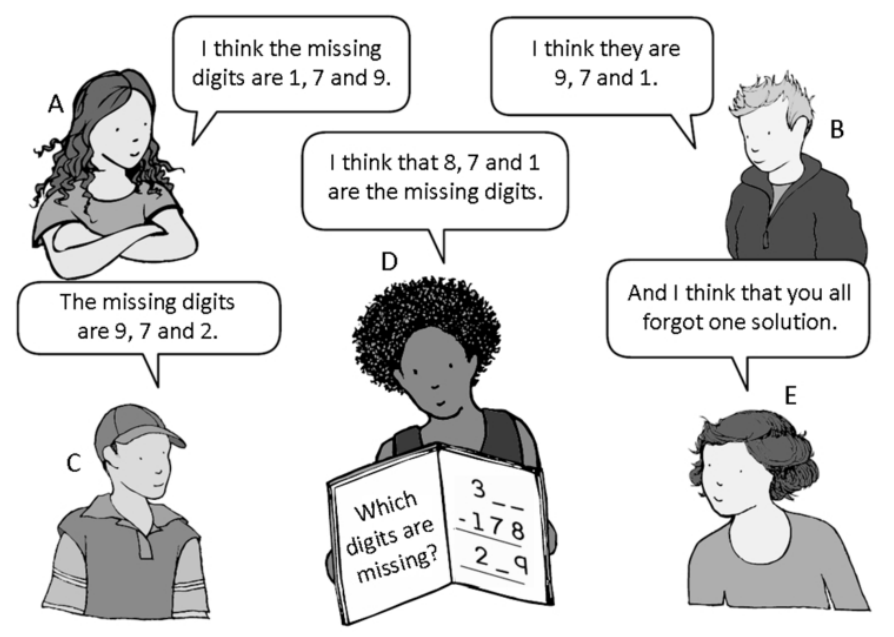

Figure 2: Concept Cartoon from the first stage of data collection (source of the template of children with empty bubbles and an empty book: Dabell, Keogh and Naylor, 2008: 2.10).

In the end of the school year we assigned the students the Concept Cartoon shown in Fig. 3. The task discussed in this picture has three solutions. Similarly as in the initial worksheet, the first solution is directly described in bubbles B and A, and the possibility of existence of another solution is just indirectly mentioned in a bubble $\mathrm{E}$.

Both worksheets were treated by 25 students ( 4 students absented at lessons where data were collected). One of the students made such mistakes in calculations that the data are not applicable for our purpose. Thus, 24 students remained relevant for the study.

During data analysis we registered combinations of bubbles that were chosen by individual students as right. We accepted only responses supported by appropriate justification.

We focused on two main aspects related to open approach to mathematics: searching for other (all) solutions - the case of choosing a bubble E, and acceptance of different forms of notation of a given solution - the case of choosing both bubbles $\mathrm{A}$ and $\mathrm{B}$.

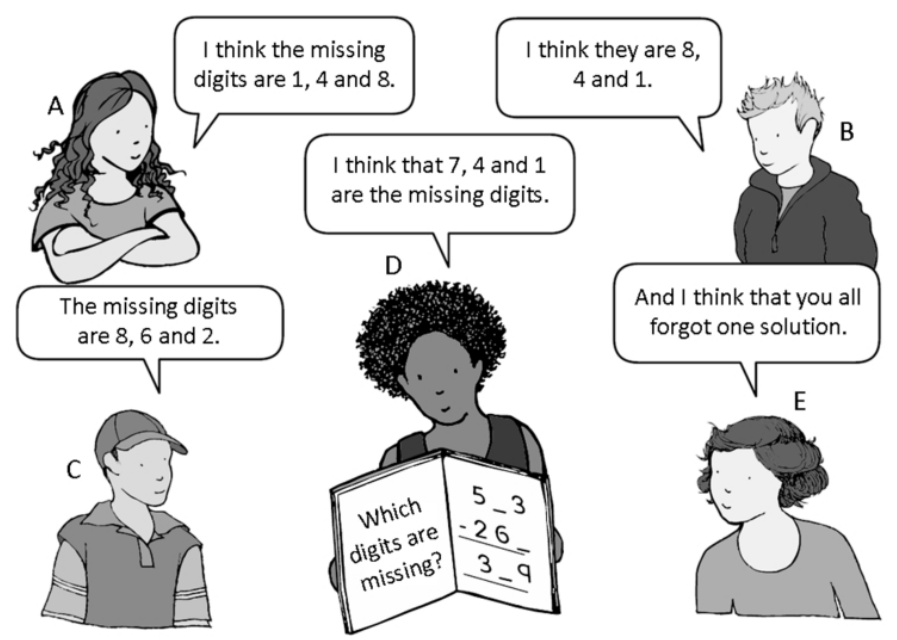

Figure 3: Concept Cartoon from the second stage of data collection; (source of the template of children with empty bubbles and an empty book: Dabell, Keogh and Naylor, 2008: 2.10). 


\section{Second part of the research: open approach in problem posing}

The second part of the research relates to problem posing. It extends the first part of the research, and aspires to look for answers to the research question "Do the shifts towards open approach observed when participants solve problems appear also when they pose problems?"

In this part of the research data collection took place in one stage: several months after the end of the first part of the research, during a course on didactics of mathematics.

In this case we asked the participants to create their own Concept Cartoon that could be assigned to primary school pupils during a lesson on mathematics. Openness of the task was neither required, nor mentioned in the assignment; the participants did not know about the relation between the first and the second parts of the research.

They worked on the task individually, in the form of a written homework; the homework was treated by 26 participants.

During data analysis we focused again on aspects of open approach as in the first part of the research, but this time from the perspective of problem posing. We concentrated on whether the Concept Cartoons posed by participants would allow the pupils to experience open approach to mathematics, i.e. to experience searching for various solutions, searching for various ways of solving or deciding between different forms of notation of a given solution.

\section{Results}

\section{Problem solving \& searching for other (all) solutions}

While observing responses related to this aspect, we realized that the most frequent strategy in the first worksheet consisted in checking the alternatives with given digits (i.e. alternatives in bubbles A to D), and by paying no attention to the possibility mentioned in a bubble E. Students who used this strategy found just one solution of the task, and did not search for any other. In the second worksheet, some of these students used again the same strategy, some of them responded to the bubble E and searched for one other solution, and some of them worked systematically and found all three solutions. For proportional details see Fig. 4.
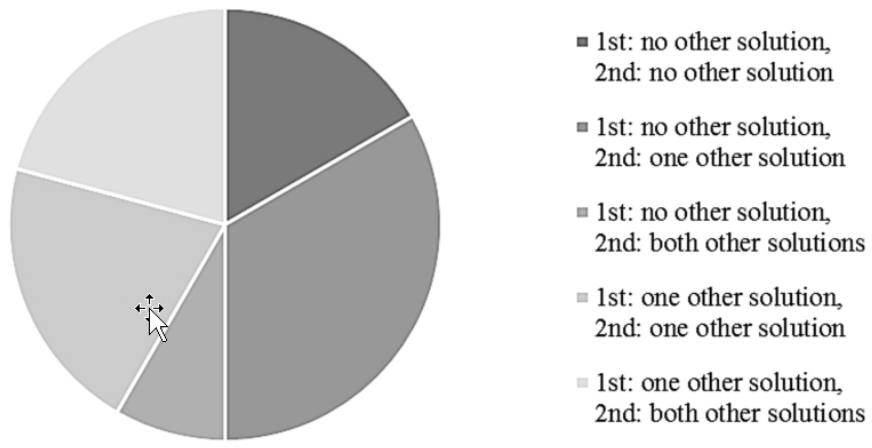

Figure 4: Searching for other solutions presented in 1st and 2 nd worksheets, $n=24,2014-2015$ (source: own calculation).

The less frequent strategy in the first worksheet consisted in paying attention to the bubble $\mathrm{E}$, and thus in searching for a solution not listed in bubbles. But only one of the students worked systematically and verified that there are no other solutions. In the second worksheet, some of these students again paid attention to the bubble $\mathrm{E}$ and searched for one solution not listed in bubbles. But they did not find out that there are two such solutions. The rest of the students this time worked systematically and found all three solutions. For proportional details see Fig. 4.

Summarized: after the active participation in the course, none of the respondents got worse in the monitored aspect, and majority of the respondents improved in the monitored aspect.

\section{Problem solving \& acceptance of different forms of notation of a given solution}

While observing responses related to this aspect, we realized that in the first worksheet majority of the students accepted the bubble B and did not accept the bubble A. In the second worksheet, some of these students used again the same strategy, some of them accepted both the bubbles B and A. For proportional details see Fig. 5.

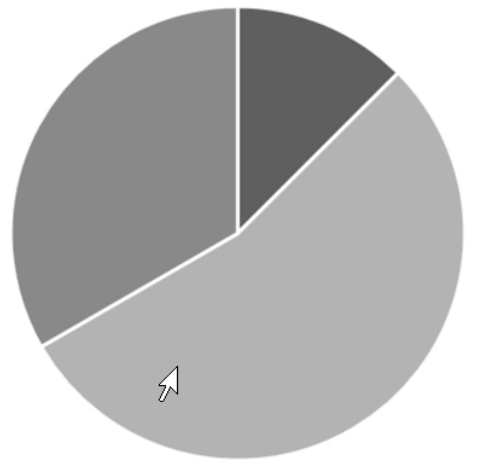

- 1st: accept B, not accept A, 2nd: accept B, not accept A

1st: accept B, not accept A, 2nd: accept B, accept A

- 1st: accept B, accept A 2nd: accept B, accept A

Figure 5: Acceptance of different forms of notation presented in 1st and 2nd worksheets, $n=24,2014-2015$ (source: own calculation).

All the students who accepted both B and A bubbles in the first worksheet used the same strategy in the second worksheet. For proportional details see Fig. 5.

Summarized: after the participation in the course, none of the respondents got worse in the monitored aspect, and majority of the respondents improved in the monitored aspect.

\section{Problem posing \& allowing pupils to experience open approach to mathematics}

Among 26 Concept Cartoons posed by participants we found 7 that could allow pupils to experience searching for various solutions, and 2 that worked with different notations of a given solution. The remaining 17 participants posed Concept Cartoons on tasks with unique solution, unique way of solving, and unique notation, i.e. tasks that did not employ open approach. None of the participants posed Concept Cartoon that would allow to experience searching for various ways of solving.

From the perspective of individual respondents, the extent of openness proposed during problem posing was not related to the extent of openness presented during problem solving: authors of Concept Cartoons allowing to experience open approach belonged to various groups from diagrams in Fig. 4 and 5.

For illustration, we shall show four of the Concept Cartoons; three of them employing open approach, the fourth not. The first Concept Cartoon was posed by a participant who belonged to both last groups in the diagrams, i.e. a student who had already employed open approach before her participation in the inquirybased course. She prepared a task with eight solutions, two of 
them directly described in bubbles; one of the bubbles comprises of a question whether there may be more solutions (see Fig. 6).

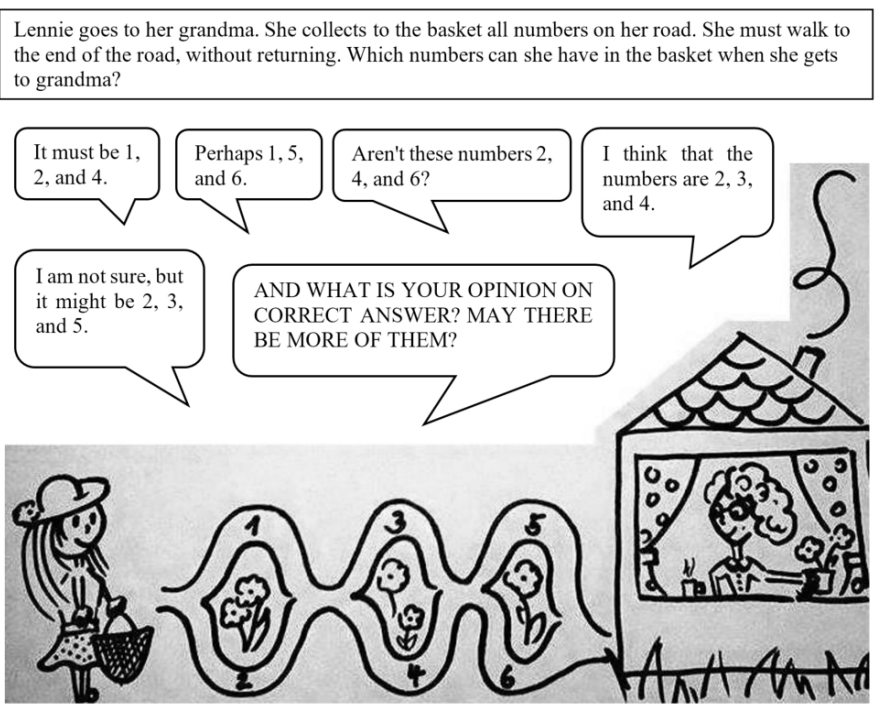

Figure 6: Concept Cartoon posed by the first student; translated from Czech.

The second Concept Cartoon was posed by a participant who improved during the inquiry-based course in searching for other solution, namely a participant who belonged to the third group in Fig. 4, and to the first group in Fig. 5. She prepared a task with two solutions; both of them directly displayed in bubbles (see Fig. 7).

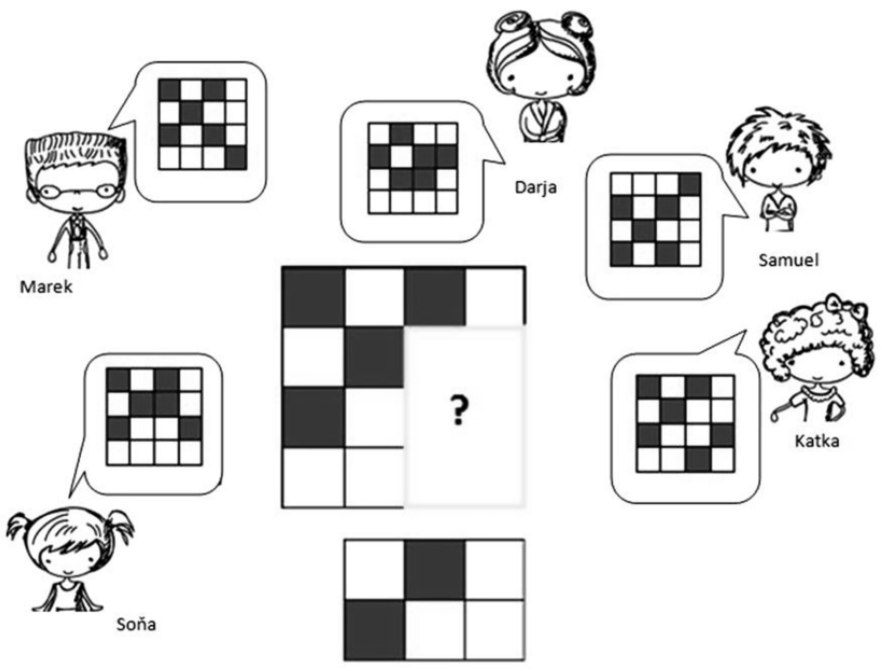

Figure 7: Concept Cartoon posed by the second student.

The third Concept Cartoon was posed by a participant who belonged to the first group in Fig. 4, and to the second group in Fig. 5, i.e. a participant who showed no shift in searching for other solutions, and improved only in acceptance of different forms of notation. Although he did not search for other solutions during his own problem solving, he posed Concept Cartoon with task open from several perspectives: the task allows various ways of grasping, and the correctness of the bubbles is conditional (see Fig. 8). The task grows from a certain real-life situation on a financial literacy issue, and provokes many related questions: Are newspapers distributed also on weekends? Is the paperboy able to sell always all newspapers appointed for the day? How often the salary is paid in particular jobs? Are the time conditions and other job requirements of particular jobs suitable for Tom?...

\section{Part-time jobs offers:}

1) STOREMAN: jobholder will get $700 \mathrm{CZK}$ each week 2) PAINTER: jobholder will get $3000 \mathrm{CZK}$ each month

3) PAPERBOY: jobholder will get 10 newspapers each day, and for any sold newspaper will get $10 \mathrm{CZK}$

$\underline{\text { Tom: }}$ I need to earn as fast as possible $10000 \mathrm{CZK}$ for a new notepad. Which of the jobs will be best for me?

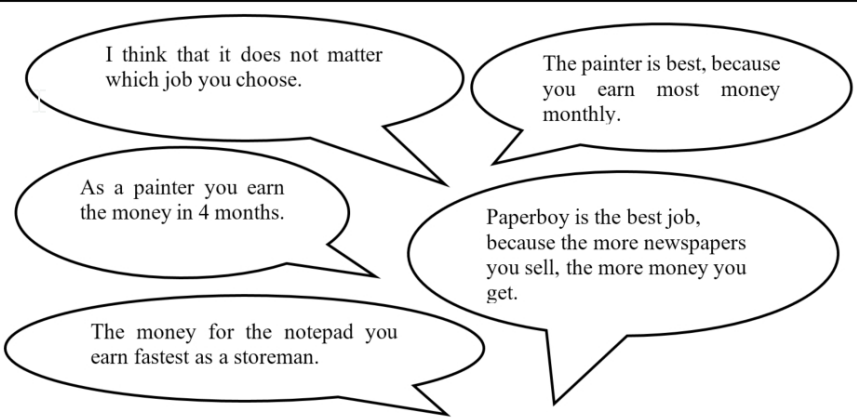

Figure 8: Concept Cartoon posed by the third student; translated from Czech.

The fourth Concept Cartoon was posed by a participant who belonged to the third group in both diagrams, i.e. a participant who had already accepted various notations before her participation in the inquiry-based the course, and who improved during the course in searching for other solutions (but only partially). She prepared a task with one correct solution, put this correct solution to one of the bubbles, and four incorrect alternatives to other bubbles. One of the incorrect alternatives mentions the possibility that the correct solution was not pronounced yet (see Fig. 9). At the first sight the Concept Cartoon looks like the ones in Fig. 2 and Fig. 3: numbers in different bubbles are ordered differently (some from the smallest, some not), and the bubble without numbers indirectly points on an absent solution. But a task with unique solution is not suitable for such an arrangement. Moreover, the participant did not take advantage of the potential of the task, e.g. a bubble with numbers from the correct solution but differently ordered would notably enrich the discussion. Such a Concept Cartoons does not allow the pupil to experience open approach to mathematics.

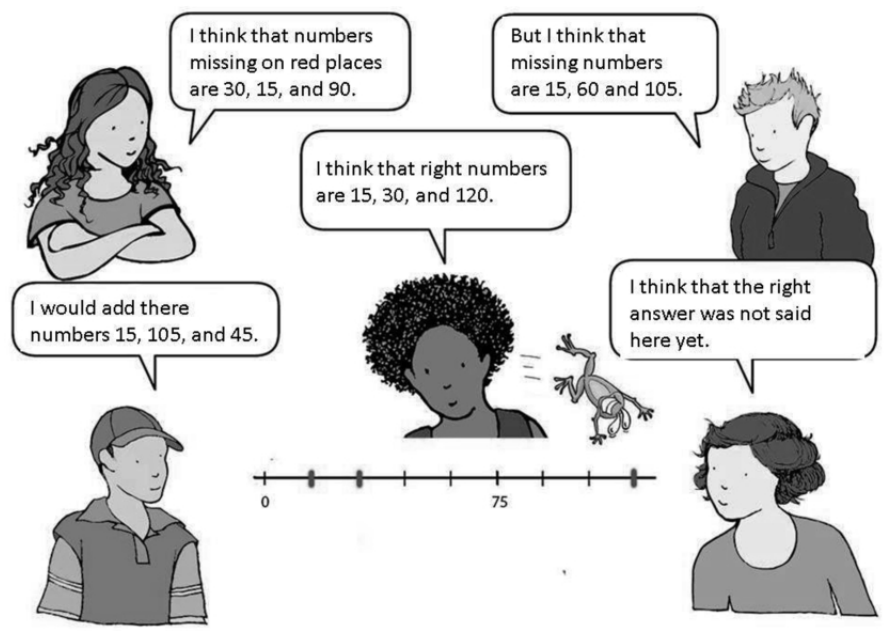

Figure 9: Concept Cartoon posed by the fourth student; translated from Czech (source of the template of children with empty bubbles: Dabell, Keogh and Naylor, 2008: 2.10).

\section{Discussion}

Our results are in accordance with findings of various research on impact of inquiry-based education on students' (or pupils') knowledge and attitudes. As summarizes the survey study by Bruder and Prescott (2013), most of the empirical studies dealing with inquiry-based education show positive gains 
for the students, mostly on processes, rarely on content. The greatest gains in both content and process show studies oriented on guided inquiry, i.e. the type of inquiry we employed in our study. In this context we should not neglect an extensive research conducted by Jiang and McComas (2015), measuring the effects of inquiry-based education in the field of science through PISA data. They ascertained that among various types of inquiry, the guided inquiry have the greatest gains in students achievement.

Open approach to mathematics was longitudinally investigated e.g. by Boaler (1998) who showed that this method brings same or better content knowledge of pupils and students than in the traditional classrooms, and significantly better attitudes towards mathematics.

In the form of polyvalent tasks the open approach can also facilitate differentiation in the classroom - pupils can respond to the task at a variety of levels (Sullivan and Clarke, 1992). In our research we got use of this feature of polyvalent tasks while diagnosing knowledge through Concept Cartoons: when the Concept Cartoon is based on a polyvalent task, the analysis allow to determinate various levels of solver's knowledge.

The above findings also correspond with our other research involving the same group of participants: apart the shifts toward open approach to mathematics reported here we already detected changes in participants' approach to argumentation (a shift towards more efficient use of counter-examples, and a shift from using empirical arguments to attempts of using deductive arguments; see Samková and Tichá, 2016a), and changes in participants' beliefs about mathematics (e.g. the newly emerged beliefs that discovering a thing by oneself helps remembering the thing, that solving graded series of tasks help learning by allowing to understand simpler issues first, that linking theory to examples or everyday reality helps understanding; we also observed signs of an ongoing change of the belief that mathematics is about memorizing formulas and procedures many participants uncovered deficiencies of this belief during the course, and started to explore its possible alternatives; for details see Samková and Tichá, 2016b).

In our study we got use of Concept Cartoons, an educational tool backgrounded by a rather rich research in the field of science education, especially with focus on its role in primary school classroom (Naylor and Keogh, 2013). We broadened the range of the tool, and investigate from various perspectives its possible usage in mathematics education of (future) primary school teachers. We analyse its supportive, educational and diagnostic role in teachers' education, and observe its benefits in the fields of problem solving and problem posing. Our findings are consistent with general research, e.g. the case of the student who posed the Concept Cartoon in Fig. 8 confirms the importance of linking problem solving and problem posing that was emphasized several times in recently issued monograph on problem posing (Singer, Ellerton and Cai, 2015): the student who was rather weak in problem solving from the perspective of open approach, posed Concept Cartoon that was the most open of all. Such cases illustrate how diverse information are provided by problem solving and problem posing, and how these information can complement each other. The revelation that there might be students who are more successful in problem posing and in grasping real-life situation than in their own solving problems of school mathematics corresponds also with findings presented by Koman and Tichá (1998) in the context of grasping real-life situations.

Additionally, we also use Concept Cartoons while preparing future teachers for their own teaching; such a tool helps them become aware of possible pupils' mistakes that can occur in the classroom. Similar but not the same tool called discussion prompt sheets is mentioned by Ryan and Williams (2011) in their research about pupils' misconceptions in elementary mathematics.

From the applicability point of view, inquiry-based education, open approach, problem solving and problem posing are all of a high level of importance. Nowadays economics requires people who are highly adaptable to change, who are able to utilize their knowledge in different contexts (OECD, 2005), and the above approaches facilitate this adaptability in students: open approach can cultivate students' divergent thinking including fluency, flexibility, and originality (Kwon, Park and Park, 2006; Nohda, 2000), inquiry-based education rich in problem solving and problem posing can develop creativity (Silver, 1997). Also studies on engineering creativity indicate the importance of facilitating problem-solving skills in future engineers (Zhou, 2012). Last but not least we have to mention connections to managerial skills, since problem solving is one of the managerial competences, alongside with creativity, analytical thinking, teamwork, planning, organising, checking, flexibility, etc. (Hricova, 2015) - all of these take place and hopefully develop during inquiry-based education (Dorrier and Maaß, 2014) or during solving an open problem (Nohda, 2000).

Summarized, our research follows and deepens findings of wide range of relevant research, it returns and reacts to some remarkable issues from elder research (open problems, grasping situations), and reacts to recent issues (inquiry-based education).

Weak point of our research might consist in size of the sample, and in homogenous nature of the sample. In spite of these weaknesses, we believe that the results are applicable in teacher education also at other universities. From our experience at educational conferences and seminars (national and international) we may say that the issue is well accepted by the educational community.

\section{Conclusion}

During our study we implemented inquiry-based education into a university course on mathematics for future primary school teachers, and observed participants of the course from the perspective of three aspects related to open approach to mathematics: during problem solving we investigated whether they would search for all solutions of a multiple-solution task, and whether they were able to accept different forms of notation of a given solution, during problem posing we investigated whether they would pose problems allowing pupils to experience open approach.

Collected data showed that in the beginning of the course majority of the participants tended to search only one solution of a task, did not attempts to seek any other solutions, and did not try to verify whether there might be any other solutions. Further, majority of the participants tended to accept only one form of notation of a given solution. Based on our experience, such tendencies use to be very common among future teachers, and 
hard to change. After the active participation in the inquiry-based course, we detected in the participants shifts from searching for just one solution to searching for more solutions, shifts from unsystematic search for some solutions to systematic search for all solutions, and also shifts towards accepting various forms of notations of a given solution.

We ascertained that each of the participants improved during the course at least in one of the monitored aspects, and that none of the participants got worse in any of the aspects.

As a positive signal we see the fact, that some of the participants were able to implement open approach while posing problems, even though the openness of the posed task was not required.

We consider open approach to mathematics as an important component of future teachers' education. It helps develop their pedagogical content knowledge, e.g. by making them ready to accept different ways of solving and different solutions proposed by pupils in the classroom.

Undoubtedly we can say that the active participation in the inquiry-based university mathematics course developed future primary school teachers' open approach to mathematics, and thus strengthened their professional competences.

\section{Acknowledgement}

This article was supported by the Czech Science Foundation under Grant 'Enhancing mathematics content knowledge of future primary teachers via inquiry based education', project No. 14-01417S. This article was supported by RVO 67985840.

\section{References}

Artigue, M. and Blomhøj, M. (2013) 'Conceptualizing inquirybased education in mathematics', ZDM Mathematics Education, vol. 45, no. 6, pp. 797-810. http://dx.doi.org/10.1007/s11858013-0506-6

Boaler, J. (1998) 'Open and closed mathematics: student experiences and understanding', Journal for Research in Mathematics Education, vol. 29, no. 1, pp. 41-62. http://dx.doi. org/10.2307/749717

Bruder, R. and Prescott, A. (2013) 'Research evidence on the benefits of IBL', ZDM Mathematics Education, vol. 45, no. 6, pp. 811-822. http://dx.doi.org/10.1007/s11858-013-0542-2

Brunner, J. S. (1966) Toward a theory of instruction, Cambridge: Belknap Press. http://dx.doi.org/10.1177/019263656605030929 Dabell, J., Keogh, B. and Naylor, S. (2008) Concept Cartoons in Mathematics Education (CD ROM), Sandbach: Millgate House Education.

Dewey, J. (1938) Logic: The theory of inquiry, New York: Holt. Dorier, J. - L. and Maaß, K. (2014) 'Inquiry-based mathematics education', in Lerman, S. (ed.) Encyclopedia of Mathematics Education, Dordrecht: Springer. http://dx.doi.org/10.1007/97894-007-4978-8_176

Freudenthal, H. (1973) Mathematics as an educational task, Dordrecht: Reidel Publishing Company.

Hellmig, L. (2010) 'Effective 'blended' professional development for teachers of mathematics: design and evaluation of the "UPOLA"-program', in Durand-Guerrier, V., SouryLavergne, S. and Arzarello, F. (eds.) Proceedings of CERME 6, Lyon, France: Institut National de Recherche Pédagogique, pp. 1694-1703.

Hošpesová, A. and Tichá, M. (2013) 'One possible way of training teachers for inquiry based education', in Ubuz, B., Haser, C. and Mariotti, M. A. (eds.) Proceedings of the Eighth Congress of European Research in Mathematics Education (CERME 8), Ankara, Turkey: Middle East Technical University, pp. 3105-3114.

Hricová, D. (2015) 'The formation of a performance evaluation model', in Krejčí, I., Flégl, M. and Houška, M. (eds.) Proceedings of the 12th International Conference Efficiency and Responsibility in Education 2015 (ERIE 2015), Prague, Czech Republic: Czech University of Life Sciences, pp. 181-189.

Jiang, F. and McComas, W. F. (2015) 'The effect of inquiry teaching on student science achievement and attitudes: evidence from propensity score analysis of PISA data', International Journal of Science Education, vol. 37, no. 3, pp. 554-576. http:// dx.doi.org/10.1080/09500693.2014.1000426

Keogh, B. and Naylor, S. (1993) 'Learning in science: another way in', Primary Science Review, vol. 26, pp. 22-23.

Koman, M. and Tichá, M. (1988) Basic Research in Didactics of Mathematics in Czechoslovakia. Comment to the Development of the Functional and Algorithmic Approaches to Problem Solving, Praha: MÚ ČSAV, Preprint Series, No. 34.

Koman, M. and Tichá, M. (1998) 'On travelling together and sharing expenses', Teaching Mathematics and Its Applications, vol. 17, no. 3, pp. 117-122. http://dx.doi.org/10.1093/ teamat/17.3.117

Kwon, O. N., Park, J. S. and Park, J. H. (2006) 'Cultivating divergent thinking in mathematics through asn open-ended approach', Asia Pacific Education Review, vol. 7, no. 1, pp. 5161. http://dx.doi.org/10.1007/bf03036784

Naylor, S. and Keogh, B. (2013) 'Concept Cartoons: What have we learnt?', Journal of Turkish Science Education, vol. 10, no. 1, pp. 3-11.

Naylor, S., Keogh, B. and Downing, B. (2007) 'Argumentation and primary science', Research in Science Education, vol. 37, pp. 17-39. http://dx.doi.org/10.1007/s11165-005-9002-5

Nohda, N. (1995) 'Teaching and evaluating using "open-ended problems" in the classroom', ZDM Mathematics Education, vol. 27, no. 2, pp. 57-61.

Nohda, N. (2000) 'Teaching by open-approach method in Japanese mathematics classroom', in Nakahara, T. and Koyama, M. (eds.) Proceedings of PME 24 (Vol. 1), Hiroshima, Japan: Hiroshima University, pp. 39-53.

Novotná, J., Eisenmann, P., Přibyl, J., Ondrušová, J. and Břehovský, J. (2014) 'Problem solving in school mathematics based on heuristic strategies', Journal of Efficiency and Responsibility in Education and Science, vol. 7, no. 1, pp. 1-6. http://dx.doi.org/10.7160/eriesj.2014.070101

Novotná, J., Eisenmann, P. and Přibyl, J. (2015) 'Are heuristic strategies a domain only for gifted pupils?', in Krejčí, I., Flégl, M. and Houška, M. (eds.) Proceedings of the 12th International Conference Efficiency and Responsibility in Education 2015 (ERIE 2015), Prague, Czech Republic: Czech University of Life Sciences, pp. 406-413.

Organization of Economic Cooperation and Development (2005) The selection and definition of key competencies: executive summary, Paris, France: OECD.

Patáková, E. (2013) 'The quality of mathematical problems - evaluation and self-evaluation', Journal of Efficiency and Responsibility in Education and Science, vol. 6, no. 3, pp. 143154. http://dx.doi.org/10.7160/eriesj.2013.060302

Pehkonen, E. (1995) 'Introduction: Use of open-ended problems', International Reviews on Mathematical Education, vol. 27 , no. 2 , pp. 55-57. 
Ryan, J. and Williams, J. (2011) Children's mathematics 4-15. Learning from errors and misconceptions, Berkshire: Open University Press.

Samková, L. and Hošpesová, A. (2015) 'Using Concept Cartoons to investigate future teachers' knowledge', in Krainer, K. and Vondrová, N. (eds.) Proceedings of the Ninth Congress of the European Society for Research in Mathematics Education (CERME 9), Prague, Czech Republic: Charles University, Faculty of Education, pp. 3241-3247.

Samková, L., Hošpesová, A., Roubíček, F. and Tichá, M. (2015) 'Badatelsky orientované vyučování matematice', Scientia in educatione, vol. 6, no. 1, pp. 91-122.

Samková, L. and Naylor, S. (2015) 'Concept Cartoons as educational and diagnostic tool', in Novotná, J. and Moraová, H. (eds.) Proceedings of International Symposium Elementary Maths Teaching SEMT 15, Prague, Czech Republic: Charles University, Faculty of Education, pp. 374-376.

Samková, L. and Tichá, M. (2015) 'Investigating future primary teachers' grasping of situations related to unequal partition word problems', in Sabena, C. and Di Paola, B. (eds.) Quaderni di Ricerca in Didattica (Mathematics), n. 25, Supplemento n. 2. Proceedings CIEAEM 67, Teaching and learning mathematics: resources and obstacles, Palermo, Italy: G.R.I.M., pp. 295-303. Samková, L. and Tichá, M. (2016a) 'Developing views of proof of future primary school teachers', in Balko, L'., Szarková, D., and Richtáriková, D. (eds.) Proceedings, 15th Conference on Applied Mathematics Aplimat 2016, Bratislava, Slovak Republic: STU, pp. 987-998.

Samková, L. and Tichá, M. (2016b) 'On the way to enhance future primary school teachers' beliefs about mathematics via inquiry based university courses'. Research report accepted for the conference 13th International Congress on Mathematical Education (ICME-13), July 2016, Hamburg, Germany.

Samková, L. and Tichá, M. (2016c) 'Developing open approach to mathematics in future primary school teachers', in Flégl, M., Houška, M., and Krejčí, I. (eds.) Proceedings of the 13th International Conference on Efficiency and Responsibility in Education 2016 (ERIE 2016), Prague, Czech Republic: Czech University of Life Sciences, pp. 494-501.

Samková, L., Tichá, M. and Hošpesová, A. (2015) 'Error patterns in computation in Concept Cartoons', in Novotná, J. and Moraová, H. (eds.) Proceedings of International Symposium Elementary Maths Teaching SEMT 15, Prague, Czech Republic: Charles University, Faculty of Education, pp. 390-391.

Silver, E. A. (1997) 'Fostering creativity through instruction rich in mathematical problem solving and problem posing', ZDM, vol. 29, no. 3, pp. 75-80. http://dx.doi.org/10.1007/ s11858-9970003-X

Singer, F. M, Ellerton, N. F. and Cai, J. (eds.) (2015) Mathematical Problem Posing. From Research to Effective Practice, New York: Springer. http://dx.doi.org/10.1007/978-1-4614-6258-3

Sullivan, P. and Clarke, D. (1992) 'Problem solving with conventional mathematics content: responses of pupils to open mathematical tasks', Mathematics Education Research Journal, vol. 4, no. 1, pp. 42-60. http://dx.doi.org/10.1007/bf03217231

Tichá, M. (2009) 'Problem posing in teacher training and as a research object in didactics: Two complementary perspectives', in Spagnolo, F. (ed.) Quaderni di Ricerca in Didattica (Scienze Matematiche), n. 19, Supplemento n. 2. Proceedings CIEAEM 61, Palermo, Italy: G.R.I.M., pp. 445-449.

Vyšín, J. (1976) 'Genetická metoda ve vyučování matematice', Matematika a fyzika ve škole, vol. 6, pp. 582-593.

Wittmann,E.Ch.(1974) Grundfragendes Mathematikunterrichts,
Stuttgart: Vieweg. http://dx. doi.org/10.1007/978-3-322-856685

Wittmann, E. Ch. (2001) 'Developing mathematics education in a systemic process', Educational Studies in Mathematics, vol. 48, no. 1, pp. 1-20. http://dx.doi.org/10.1023/a:101 5538317850 Zhou, Ch. (2012) 'Teaching engineering students creativity: a review of applied strategies', Journal of Efficiency and Responsibility in Education and Science, vol. 5, no. 2, pp. 99114. http://dx.doi.org/10.7160/eriesj.2012.050205 